\title{
Biocontrol of Aflatoxins Using Non-Aflatoxigenic Aspergillus flavus: A Literature Review
}

\author{
Rahim Khan ${ }^{1}$ (D), Farinazleen Mohamad Ghazali ${ }^{1, *}$, Nor Ainy Mahyudin ${ }^{2,3}$ (D) \\ and Nik Iskandar Putra Samsudin 1,4 (D) \\ 1 Department of Food Science, Faculty of Food Science and Technology, Universiti Putra Malaysia, \\ Serdang 43400, Malaysia; sirifrahim1@yahoo.com (R.K.); nikiskandar@upm.edu.my (N.I.P.S.) \\ 2 Department of Food Service and Management, Faculty of Food Science and Technology, Universiti Putra \\ Malaysia, Serdang 43400, Malaysia; norainy@upm.edu.my \\ 3 Laboratory of Halal Science Research, Halal Products Research Institute, Universiti Putra Malaysia, \\ Serdang 43400, Malaysia \\ 4 Laboratory of Food Safety and Food Integrity, Institute of Tropical Agriculture and Food Security, \\ Universiti Putra Malaysia, Serdang 43400, Malaysia \\ * Correspondence: farinazleen@upm.edu.my; Tel.: +60-12219-8912
}

check for updates

Citation: Khan, R.; Ghazali, F.M.; Mahyudin, N.A.; Samsudin, N.I.P. Biocontrol of Aflatoxins Using Non-Aflatoxigenic Aspergillus flavus: A Literature Review. J. Fungi 2021, 7, 381. https://doi.org/10.3390/ jof7050381

Academic Editor: Scott G. Filler

Received: 16 March 2021

Accepted: 8 May 2021

Published: 12 May 2021

Publisher's Note: MDPI stays neutral with regard to jurisdictional claims in published maps and institutional affiliations.

Copyright: (C) 2021 by the authors. Licensee MDPI, Basel, Switzerland. This article is an open access article distributed under the terms and conditions of the Creative Commons Attribution (CC BY) license (https:/ / creativecommons.org/licenses/by/ $4.0 /)$.

\begin{abstract}
Aflatoxins (AFs) are mycotoxins, predominantly produced by Aspergillus flavus, A. parasiticus, A. nomius, and $A$. pseudotamarii. AFs are carcinogenic compounds causing liver cancer in humans and animals. Physical and biological factors significantly affect AF production during the pre-and post-harvest time. Several methodologies have been developed to control AF contamination, yet; they are usually expensive and unfriendly to the environment. Consequently, interest in using biocontrol agents has increased, as they are convenient, advanced, and friendly to the environment. Using non-aflatoxigenic strains of $A$. flavus $\left(\mathrm{AF}^{-}\right)$as biocontrol agents is the most promising method to control AFs' contamination in cereal crops. $\mathrm{AF}^{-}$strains cannot produce AFs due to the absence of polyketide synthase genes or genetic mutation. $\mathrm{AF}^{-}$strains competitively exclude the $\mathrm{AF}^{+}$strains in the field, giving an extra advantage to the stored grains. Several microbiological, molecular, and field-based approaches have been used to select a suitable biocontrol agent. The effectiveness of biocontrol agents in controlling AF contamination could reach up to $99.3 \%$. Optimal inoculum rate and a perfect time of application are critical factors influencing the efficacy of biocontrol agents.
\end{abstract}

Keywords: aflatoxins; biocontrol; non-aflatoxigenic Aspergillus flavus; biotic and abiotic factors

\section{Introduction}

Aflatoxins (AFs) are secondary metabolites produced by Aspergillus flavus, A. parasiticus, A. nomius, and A. pseudotamarii [1,2]. AFs are organic compounds with lower molecular weight, typically produced by fungal mycelia and accumulated in conidia and sclerotia. AFs contaminate a wide range of crops, including corn, oilseeds, rice, and nuts [3-6]. AFs contamination in cereals may occur during pre- or post-harvest stages $[7,8]$. Hot temperature and high humidity stimulate fungal growth in fields and storage. Contamination by AFs is responsible for substantial commercial losses throughout the world [9-11]. AFs are among the most toxic compounds that adversely affect humans and animals' health [12-17]. AFs are mutagenic, teratogenic, genotoxic, and carcinogenic compounds, causing severe diseases in humans, poultry, fishes, and cattle under long-term exposure [18,19]. AFs can penetrate the feed and food chain, posing a threat to even newborns [20,21]. While several AFs were currently identified, $\mathrm{AFB}_{1}, \mathrm{AFB}_{2}, \mathrm{AFG}_{1}$, and $\mathrm{AFG}_{2}$ are the four most significant AFs. The IARC (International Agency for Research on Cancer) classifies AFB 1 as the most toxic, mutagenic, and Group 1 human carcinogen [22-24], causing chronic and acute diseases in children and the elderly. $\mathrm{AFB}_{1}$ carcinogenicity has long been linked to the liver; however, recent epidemiological studies revealed that it was also carcinogenic 
to the pancreas, kidney, bone, bladder, and central nervous system [25-28]. According to El-Serag [29], Bruix et al. [30], and Yoshida et al. [31], $\mathrm{AFB}_{1}$ exposure could increase the hepatocellular carcinoma (HCC) risk for up to 30 times, particularly in those who infected with hepatitis $B$ virus. The inhalation of dust contaminated by $\mathrm{AFB}_{1}$ may cause tumors in humans' respiratory tracts [32]. Furthermore, $\mathrm{AFB}_{1}$ disturbs the cytochrome $\mathrm{P} 450$ enzymes involved in steroid production [33]. Sometimes, $\mathrm{AFB}_{1}$ could get into the blood-testis barrier, resulting in spermatogenesis disorder [34]. Based on toxicological syndromes, AFs contamination can be divided into acute aflatoxicosis and chronic aflatoxicosis.

Acute aflatoxicosis is distinguished by a high-dose exposure of $\mathrm{AFB}_{1}$ for a short time, causing hepatotoxicity $[35,36]$. Acute aflatoxicosis is characterized by vomiting, fever, liver injury, pulmonary or cerebral edema, anemia, necrosis, diarrhea, kidney failure, and fatigue $[37,38]$. Several incidences of acute aflatoxicosis are reported in India, Malaysia, and Kenya [39-42]. In contrast, chronic aflatoxicosis is a low-dose exposure for a long duration, causing cancer and other severe diseases in humans. Some research reported that chronic exposure to $\mathrm{AFB}_{1}$ caused the deaths of 250,000 people in Africa and China [43-45]. Human exposure to AFs can be direct or indirect. The inhalation of $\mathrm{AFB}_{1}$-contaminated dust is an excellent example of direct exposure to AFs, resulting in the tumor in the human respiratory tract. On the other hand, the intake of AF-contaminated milk $\left(\mathrm{AFM}_{1}\right)$ and other dairy products carried over contaminated feed is indirect exposure to AFs. The consumption of eggs and animal meat contaminated by AFs is another example of indirect exposure to AFs. Kaplan et al. [46] estimated human average intake of AFs at around $10-200 \mathrm{ng} / \mathrm{kg}$ per day. Humans' health risks related to contaminated food consumption are becoming a serious problem all over the world. Countries where strict rules for AFs are not implemented, resulting in high health risks related to AFs exposure. Therefore, every country should implement strict rules for AF levels in their food products [47].

\section{Global Distribution of Aspergillus flavus and Aflatoxins}

Aspergillus section Flavi contains the most prevalent aflatoxigenic fungi, including $A$. flavus and $A$. parasiticus. The less prevalent aflatoxigenic species in this section are A.nomius, A. pseudotamarii, A. bombysis, and A. parvisclerotigenus [48]. Aspergillus species are remarkably different in AF production; some are aflatoxigenic while others are nonaflatoxigenic $[49,50]$. Alternatively, A. flavus is the most common species in crops producing AFs, and cyclopiazonic acid and non-aflatoxigenic strains are rare [50-52]. A. flavus can be found in decaying vegetation, crops, and seeds as a saprophyte or parasite. Soil is the main source of primary inoculum responsible for infection in crops vulnerable to AF contamination. The infection of A. flavus on the aerial parts of crops is different, depending on their rhizosphere habits [53]. The hot and humid weather and the absence of suitable storage facilities are favorable conditions for the growth of A. flavus and AF production [54]. For instance, tropical and subtropical regions with climate change encourage $\mathrm{AF}^{-}$producing A. flavus to produce AFs in large quantities [55]. Corn and peanuts are the only crops consumed by humans worldwide, and unfortunately, highly vulnerable to AF contamination [56]. Around $40 \%$ of the loss of productivity due to infections caused by AFs has been increased in many developing countries [6].

\section{Factors Affecting Aflatoxin Production}

Several physical (abiotic) and biological (biotic) factors influence fungal growth and AF production [57]. In crops, AF contamination occurs during harvest, as the weather is wet due to unseasonal rains. Moreover, insect damage, drought, and heavy rainfall favor fungal growth. The degree of mycological infiltration and AF contamination varies with time and region [58]. Nature depends on fungal strains $[59,60]$ and other microbes interference, moisture content, temperature, and resulting soil conditions. Fungal spores can enter through either damaged pod walls, insects, or pollination.

Additionally, nutrient deficiency in plants may increase AF levels. Recent studies showed high levels of AF production at $25^{\circ} \mathrm{C}$ to $28^{\circ} \mathrm{C}$ [61,62]. Likewise, high humidity 
(83-88\%) and optimal $\mathrm{CO}_{2}$ and $\mathrm{O}_{2}$ have been found to influence fungal growth and AFs production [63]. Alternatively, lower concentrations of $\mathrm{CO}_{2}$ and $\mathrm{O}_{2}$ may inhibit fungal growth and AFs production. The presence or absence of certain compounds and elements can also control the AFs production, such as glucose, sucrose, and fructose that provide a suitable environment for fungal growth, while cadmium and iron slower down the fungal growth and AF production $[64,65]$.

Similarly, climate change could significantly influence the $\mathrm{AF}^{+}$life cycle, changing host-pathogen relationships and host resistance. It could directly impact the ability of $\mathrm{AF}^{+}$ species to produce AFs and their overall resilience $[66,67]$. Climate change not only affects host-pathogen relationships in specific areas but also promotes the emergence of new diseases and modifications in fungal biodiversity caused by fluctuations in their ecological niches [68-70]. Certain $\mathrm{AF}^{+}$species are declining in one environment and reappearing in other regions because of climate change. The ability of $\mathrm{AF}^{+}$species to adapt to such environmental changes can be perceived by continuously evolving combinations of AFs in food and feed.

\section{Aflatoxin Management}

Researchers are actively involved in preventing AFs production and spread, as the dangers of AFs to livestock and human health cannot be underestimated. Several preand post-harvest prevention measures, such as good agricultural practices, including deep plowing, manuring, irrigation, and maintaining water supply to the crops, are considered the best options for reducing AF contamination in crops [71-73]. Recent studies have suggested that irrigation in the late season could increase soil moisture contents and reduce the soil temperature, resulting in a decreased AF levels in crops [74]. These physical strategies, however, are not always feasible [19]. Apart from physical methods, various chemical strategies have been used for several years to lower AF levels in foods and feeds $[75,76]$. While almost all emphasis has been focused on controlling AFs contamination in crops, the most effective method is to use ammonia [77,78].

Additionally, fungicides such as amphotericin B, voriconazole, posaconazole, caspofungin, and voriconazole are effective against $A$. flavus invasion and AF contamination during pre-harvest stages. However, there is the risk of potential environmental pollution and health issues from fungicides $[79,80]$. Therefore, it is necessary to eliminate the risk by replacing chemical fungicides used with eco-friendly methods.

Crop varieties resistant to AFs are produced by breeding and genetic engineering techniques, yet no suitable resistant variety has been commercially developed [81]. Similarly, AF decontamination in food is convenient, but it is expensive and challenging [82]. Therefore, an interest in using biological control strategies has been developed, as they are helpful, friendly to the environment, and natural opponents of $\mathrm{AF}^{-}$producing strains of A. flavus [83-85]. These strategies exploit some microorganisms' antagonistic effects, such as bacteria, yeasts [86], and $\mathrm{AF}^{-}$strains [87], on the development and production of AFs produced by $\mathrm{AF}^{+}$strains. It has been reported that lactic acid bacteria such as Bacillus subtilis effectively inhibit the growth of various molds [88]. The inhibition is usually caused by competition for space and available nutrients needed for AFs biosynthesis but not for $\mathrm{AF}^{+}$strains by co-existing microorganisms.

Similarly, Flavobacterium aurantiacum has been found to remove AFs from different foodstuffs. Likewise, Pseudomonas helps develop a healthy root system by its rapid colonization of the rhizosphere, stimulating plant defense mechanisms resulting in plant resistance to pathogens [89-93]. Faraj et al. [94] demonstrated that both B. subtilis have inhibitory effects on A. flavus and AF production growth. Mixing B. subtilis with groundnut diminished the deleterious effects of A. flavus on groundnuts. Mishagi et al. [95] have reported a $60-100 \%$ reduction in $A$. flavus incidence in synthetic media when treated with $P$. cepacia bacteria. Kong et al. [96] examined the potential antifungal activity of $B$. megaterium against the growth of $A$. flavus in groundnut kernels in vitro and in vivo. However, it has been found that biological control of $\mathrm{AFs}$ using $\mathrm{AF}^{-}$strains is more productive compared 
to bacterial strains $[97,98]$. Therefore, biological control strategies based on $\mathrm{AF}^{-}$strains could be viable options for reducing pre-harvest AF contamination in crops. The efficacy of $\mathrm{AF}^{-}$strains are based on their stability and aggressiveness against $\mathrm{AF}^{+}$strains $[99,100]$. Thus, this study focuses on the recent developments in the use of $\mathrm{AF}^{-}$strains in reducing AF contamination in crops.

\section{Advantages of Biocontrol of Aflatoxins Using Non-Aflatoxigenic Aspergillus flavus}

Biocontrol methods are more effective and innovative to control AF contamination in crops. The application of biocontrol agents $\left(\mathrm{AF}^{-}\right)$carries some adaptations in fungal populations, which persist throughout the food chain. These adaptations prevent the grains from AF contamination during storage and transport; even environmental conditions are favorable for fungal growth. In biocontrol methods, the application of $\mathrm{AF}^{-}$strain in the field remarkably reduces AF contamination in crops [101,102]. Similarly, like air, AF can disperse Aspergillus spores-communities, improve safety within the treated, and positively affect neighboring fields [103]. The positive impacts of $\mathrm{AF}^{-}$strains can benefit crops and other plants for several years. This means a single dose of $\mathrm{AF}^{-}$strain could benefit the treated crop and the second season crop, which missed the treatment [104].

\section{Selection of Non-Aflatoxigenic Strains}

Biocontrol is a promising method to reduce AF contamination in crops. Recent studies reported reducing $\mathrm{AF}$ contamination by applying $\mathrm{AF}^{-}$strain to the soil around growing plants. When the crop is vulnerable to fungal attack during drought conditions, these $\mathrm{AF}^{-}$ strains competitively exclude the $\mathrm{AF}^{+}$strains in the soil and reduce AF concentrations. Dorner [105] reported the reduction in AF contamination in a cornfield using $\mathrm{AF}^{-}$strains. In other research, Dorner [105] assessed the efficacy of $\mathrm{AF}^{-}$for $\mathrm{AFs}$ control in peanuts. $\mathrm{AF}^{-}$ strains can be found in air, soil, and plants. Usually, both $\mathrm{AF}^{+}$and $\mathrm{AF}^{-}$strains mutually occur in different ecosystems. The ability of $\mathrm{AF}^{-}$strains competing with $\mathrm{AF}^{+}$strains for nutrients provides an opportunity to use them as biocontrol agents. Different techniques have been developed to discover the suitable $\mathrm{AF}^{-}$strain for biocontrol use. Some of them are based on phylogenetic features, while others on phenotypic characteristics such as sclerotial size. Based on sclerotial morphology and production, A. flavus can be divided into two distinct morphotypes, including S-strain and L-strain. The S-strains produce a large number of small-sized sclerotia ( $>400 \mu \mathrm{m}$ in diameter), whereas the L-strains produce a small number of large-sized sclerotia $(<400 \mu \mathrm{m}$ in diameter). Moreover, S-strains produce a higher concentration of AF compared to L-strains. Molecular techniques may describe the phylogenetic relationships between A. flavus strains successfully. Several polymerase chain reaction (PCR)-based pyrosequencing methods are currently being developed to detect genes responsible for AF production and discover suitable biocontrol agents [106]. Abbas et al. [107] isolated some $\mathrm{AF}^{-}$strains, including K49, F3W4, NRRL 58,974, NRRL 58,976 , and NRRL 58,988. The classification was based on their growth rate, pigmentation, fluorescence, and AF production.

\section{Efficacy of Non-Aflatoxigenic Strains as Biocontrol Agents}

$\mathrm{AF}^{-}$strains have been suggested as biocontrol agents in the hope that they would inhibit the growth of $\mathrm{AF}^{+}$and thereby reduce AFs contamination. Previous studies conducted by Erhlich [108] revealed that co-inoculation of $\mathrm{AF}^{-}$strains with $\mathrm{AF}^{+}$substantially reduced the production of AF in corn under in vitro conditions. The potential for biocontrol of AFs using $\mathrm{AF}^{-}$strains has been demonstrated under field conditions in cotton [109], peanuts [85], and corn $[97,110]$. These scientists have applied the $\mathrm{AF}^{-}$strain to the soil as infested grain cultures of barley, rice, or wheat, whereas [111] inoculated corn ears directly by injection. In the cotton studies performed by Cotty [98], the $\mathrm{AF}^{-}$strains were failed to suppress AFs contamination when it was sprayed on the cottonseed immediately before the bolls formed but were effective when sprayed on the soil later. 
Similarly, a study conducted by Abbas [63] has demonstrated that soil inoculation of $\mathrm{AF}^{-}$strain (K49) with $\mathrm{AF}^{+}$strain (F3W4) mixture significantly reduced AFs contamination (74-95\%) in corn. The degree of AF reduction found in his analysis was similar to the reductions obtained in other studies, using soil inoculation of corn and other crops. In Georgia, different studies have reported reductions in AF levels (80-87\%) in cornfields after using $\mathrm{AF}^{-}$strains against $\mathrm{AF}^{-}$producing strains of A. flavus. Likewise, in cotton fields, the application of $\mathrm{AF}^{-}$strain has decreased the amount of $\mathrm{AFB}_{1}$ from $75 \%$ to $99.8 \%$ [112]. Furthermore, Dorner et al. [99] reported the reduction of AFs concentrations between 74.3\% and $99.8 \%$ in peanut crop when they applied the $\mathrm{AF}^{-}$strains with non-aflatoxigenic strains of $A$. parasiticus. Peanuts produce fruiting bodies below the soil and hence increase the chances of biological control of AFs.

In another study, Dorner et al. [99] reported a 10-100 times increase in propagule density of the Aspergillus community when they co-inoculated the mixture of non-aflatoxigenic strains of $A$. flavus and A. parasiticus with $\mathrm{AF}^{+}$strains. Additionally, their research has shown that $A$. flavus strains were more dominant over $A$. parasiticus in the displacement of $\mathrm{AF}^{+}$strains in the soil. Dorner et al. [87] noted that the application of $\mathrm{AF}^{-}$strains to the soil would control soil-borne infection and AFs contamination in crops like peanuts; however, the same treatment in some crops like corn will be difficult. On the contrary, an $\mathrm{AF}^{-}$strain (CT3) was tested for its efficacy in AFs reduction, but it does not show effectivity like K49 to mitigate AFs contamination in corn. On the other hand, Cotty and Mellon [113] noted that co-inoculation of $\mathrm{AF} 36\left(\mathrm{AF}^{-}\right.$strain) with $\mathrm{AF}^{+}$ultimately displaced $\mathrm{AF}^{+}$strain and markedly reduced AFs contamination in cottonseed.

Moreover, Chang et al. [114] identified an $\mathrm{AF}^{-}$strain (TX9-8) by screening subgroups of $\mathrm{AF}^{-}$strains. Co-inoculation of $\mathrm{TX} 9-8$ strain with $\mathrm{AF}^{+}$strain with 1:1 ratio reduced AF production. No reduction in AF concentration has been observed when TX9-8 was injected one day later in $\mathrm{AF}^{+}$strain. This competitive exclusion was possibly due to the vigorous growth of TX9-8 against $\mathrm{AF}^{+}$strain [115]. Recently, Atehnkeng et al. [116] found La 3279 as the most efficient strain, decreasing AF contamination by $>99.3 \%$. Similarly, Ehrlich et al. [117] found the same results regarding secalonic acid reduction when they co-inoculated $\mathrm{AF}^{-}$stain with Penicillium oxalicum. They assumed that the two coinoculated species might cause competition for energy (ATP) required for the biosynthesis of secondary metabolites. There is an assumption that $\mathrm{AF}^{-}$strains competitively exclude the $\mathrm{AF}^{+}$strains when co-inoculated, resulting in the reduction of AFs contamination in crops [118]. Although $\mathrm{AF}^{-}$strains have been employed to minimize AF infections in crops, the mechanism of $\mathrm{AF}^{-}$strains' intervention on $\mathrm{AF}^{+}$strains remains unknown [119-122].

\section{Factors Affecting the Efficacy of Biocontrol Agents}

\subsection{Inoculation Method}

For many years, $\mathrm{AF}^{-}$strains have been used on cornfield soil. Although the use of $\mathrm{K} 49$ in the soil can reduce AF levels by $65 \%$ [123], the direct use of $\mathrm{AF}^{-}$strain on corn ears is immensely more efficient. A clay-based water-dispersible granule system was also developed to spray $\mathrm{AF}^{-}$strain on corn silk directly. This management decreased $\mathrm{AF}$ production by up to $97 \%$.

\subsection{Inoculum Rate}

Inoculum concentration is an essential factor for the effective control of AF contamination. Recent studies have revealed a direct relationship between the inoculum rate and $\mathrm{AF}^{\prime}$ s efficacy ${ }^{-}$strain in decreasing $\mathrm{AF}$ concentrations [124]. Studies demonstrated a significant reduction in $\mathrm{AF}$ concentration in peanuts when $\mathrm{AF}^{-}$inoculum increased from 2-50 g/L. In the USA, research was conducted in which an $\mathrm{AF}^{-}$strain (NRRL 21,368) with different quantities $(0,2,10$, and $50 \mathrm{~g})$ was applied to the cornfield [125]. The AF levels for whole kernels were 337.6, 73.7, 34.8 and $33.3 \mu \mathrm{g} / \mathrm{kg}$ for the above quantities. Other research showed AF concentrations of 718.3, 184.4, 35.9 and $0.4 \mu \mathrm{g} / \mathrm{kg}$ in corn kernels, which demonstrated $74.3 \%, 95.0 \%$ and $99.9 \%$ of AF reduction. In the following years, the 
retreated field with $\mathrm{AF}^{-}$strain showed a significant reduction in $\mathrm{AF}$ levels. According to Pitt and Hocking [119], the same results were achieved when tested in Australia.

\subsection{Optimal Time for Non-Aflatoxigenic Strains Application}

Research showed that with the concentration of $\mathrm{AF}^{-}$strains, the time of its application significantly affects their efficacy. The application of $\mathrm{AF}^{-}$strain at earlier stages significantly reduced AF levels in cotton. Similarly, Kabak and Dobson [126] suggested the co-inoculation of $\mathrm{AF}^{+}$and $\mathrm{AF}^{-}$strains (TX9-8) to reduce the $\mathrm{AF}$ contamination; however, if the $\mathrm{AF}^{-}$strain is applied one day later, $\mathrm{AF}^{+}$strains, fewer or no reduction in $\mathrm{AF}$ concentrations will be achieved.

\subsection{Abiotic Factors}

The time for the application of $\mathrm{AF}^{-}$, depends on the significant environmental conditions. Abiotic factors such as water activity and temperature directly affect $\mathrm{AF}^{-}$strains efficacy by controlling spore germination, hyphal growth, and spore-production [127].

\subsubsection{Water Activity and Growth of Non-Aflatoxigenic Strains}

Water plays a vital role in all biological practices. The main factor is the ambient water availability instead of the overall water content inside the hosts with microbes. The water content accessible to microbes in substrates is known as water activity. In substrates, water activity and total water content are interrelated. This helps to quantify the actual water content and microbial growth on the substrate. The respiration rate of $\mathrm{AF}^{-}$strain used for reducing AF needs water. The water content in food performs an essential role in the growth of fungi and other biological activities. Once water availability is low, food spontaneously attains biological safety since it reduces the decomposition process through respiration. Seasonal variation and high humidity result in water availability for food, providing a breeding place for fungi. Moist is the primary source of crop losses [128], as the water content in grains increases fungal invasion. A. flavus grows at high water content $(175 \mathrm{~g} / \mathrm{kg})$ and low temperatures $\left(10-15^{\circ} \mathrm{C}\right)$. As soon as the water content plunges from $175 \mathrm{~g} / \mathrm{kg}$ to $94 \mathrm{~g} / \mathrm{kg}$, A. flavus cannot persist at $30-40{ }^{\circ} \mathrm{C}$, demonstrating the significance of water content to the growth of fungi. Recent literature has shown that most of the molds could not propagate at a relative humidity of less than 70\% [129]. Maintaining a lower water activity in preserved seeds, particularly in tropical regions, could be more challenging; hence, seeds containing high moisture content should be dried before storage to uphold seed sustainability against the fungal activity.

\subsubsection{Temperature and Growth of Non-Aflatoxigenic Strains}

Microbial growth is exceptionally conspicuous in tropical and subtropical regions, where high temperatures and humidity prevail in most areas. High temperature and humidity favor fungal growth. Species like $A$. candidus have higher thermal tolerance, growing even in hot temperatures. However, some Aspergillus species show vigorous growth at a lower temperature $\left(10-20^{\circ} \mathrm{C}\right)$ [130]. Since Aspergillus does not reproduce at a higher temperature, the grains could be well-preserved at $40{ }^{\circ} \mathrm{C}$ [131]. Reed et al. [132] reported temperature as the primary factor in deciding field sustainability for mold. Under laboratory conditions, A. flavus multiplies when the temperature is around $10{ }^{\circ} \mathrm{C}$ [133]. However, no A. flavus growth occurred in the field environment if the temperature was less than $20^{\circ} \mathrm{C}$. Alternatively, Pitt and Hocking [119] reported faster growth for A. parasiticus at $15^{\circ} \mathrm{C}$ under laboratory conditions, while, in field environments, their growth started at $17-20{ }^{\circ} \mathrm{C}$. Thus, the application of $\mathrm{AF}^{-}$strain should be delayed until the field temperature reaches $20^{\circ} \mathrm{C}$ [134].

\subsection{Biotic Factors}

Low temperature and high water content in storage provide favorable conditions for insects, mites, and other microorganisms to grow. Insects' respiration process produces 
hot spots in seeds, causing grain charring that affects seed quality and germination. In grains, insects' activities increase the surrounding bulk's temperature and water content, providing favorable mold growth conditions. Studies have shown that seeds damaged by insects are highly susceptible to fungal contamination [135]. Some fungi absorb insects and boost their populace, while others repel pests by secreting harmful toxins. Magan [136] reported that other microorganisms and environmental conditions significantly influenced the growth of $\mathrm{AF}^{+}$strains, $\mathrm{AF}$ production, and competitiveness. Insects and mites are carriers as they carry fungal spores in their bodies. Studies have shown that mite infections supplement the A. flavus growth, as they carry fungal spores to fresh grains. Magan [136] suggested that mites are secondary vectors, carrying fungal spores into infected grains. In infected grains, mites take the fungal spores and carry them into their bodies or digestive tracts. When mites enter the fresh grain, they inoculate the fungal spores in it. The study discovered that mites seek out preferred fungi and digest a more significant percentage of their spores. Thus, these mites' heavy infestations can be linked to damage from the mites and fungi associated with them. Some mites are growth inhibitors for fungi too. Some Aspergillus species are abundantly found on Acarus siro, indicating the symbiotic relationship of the fungi with their preferred mites.

\subsection{Physiological Manipulation of Non-Aflatoxigenic Strains}

Most of the fungal niches are not persistent as they modify their features according to the external environment [137]. In unfavorable environments, xerophilic fungi produce small polyols, which allow their enzymatic systems to work efficiently. Similarly, A. flavus accumulates glycerol and erythritol in their conidia during unfavorable conditions [138]. Therefore, fungal propagules used for biocontrol must be resistant to environmental stresses [120]. According to Magan [136], agricultural management could improve the resistive performance of biocontrol agents.

Furthermore, sugar and polyol mixture could boost spore germinability in severe environmental conditions. The conidia, which have a high amount of glycerol and trehalose, grow quicker than other conidia. Likewise, Abadias et al. [139] indicated high resistivity of Candida sake to water stress as their spores contain a high concentration of glycerol and erythritol. Gasch [137] suggested a link between environmental changes and adaptation length and proposed a conidial adjustment time. Thus, a strong adaptation with a short modification time makes biocontrol agents more competitive under critical conditions.

\section{Conclusions}

The above review showed that AF contaminates many cereal crops throughout the world. AFs producing molds, including A. flavus, contaminates these commodities at different stages within the food web. The strategies and tools developed for AF analysis have their advantages and disadvantages. Despite the immense information controlling $\mathrm{AF}$, contamination continues with its harmful effects on human health, agro-industry, trade, and financial growth. This issue becomes more severe as AF's contaminated cereal crops are essential for most of the world population. The AF's contaminated crops are used in foods and feed products, resulting in many severe diseases in humans and animals. Thus, in every country, consumers and animals are persistently at risk. Aspergillus studies on their environmental conditions and the central perspective of farming systems can develop new AF control equipment. The pre-harvest methods (fungal population ecology, reproduction, and gene manipulation) are suitable for AF control; still, attention must be given to the environmental effects affecting these practices. For instance, the $\mathrm{AF}^{-}$strains sometimes worsen $\mathrm{AF}^{\prime}$ s issues by getting $\mathrm{AF}^{-}$producing genes during vegetative fusion or sexual reproduction. This can be prevented by DNA-DNA hybridization to fully understand the genetic structure of $\mathrm{AF}^{-}$strains and detect gene deletions in their chromosomes.

Furthermore, ear rot-resistant corn breeding might be a safe option for AF control, but it could take many breeding seasons due to $\mathrm{AF}^{-}$resistant genes' polygenic characteristics. The study of gene role and expression in different environmental conditions is necessary 
to understand the host-induced ecological reactions. Some resistant varieties are not fully adapted to grow in the field and are susceptible to AF contamination. Biocontrol techniques are more effective, environment-friendly, and economical for reducing AF in crops. The use of biocontrol agents brings some changes to the fungal communities that remain throughout the food chain. These changes prevent AF contamination during storage and transport; even environmental conditions are favorable for fungal growth. The application of biocontrol agents in the field remarkably reduces AF levels in crops from harvest until use. As Aspergillus spores can be dispersed by air, these fungal communities improve safety within treated fields and positively impact the neighboring fields, which means that a single dose of $\mathrm{AF}^{-}$strain could benefit the treated crop and the second season crop that missed the treatment.

Author Contributions: F.M.G.; supervision, project administration, funding acquisition; R.K.; methodology, writing - original draft preparation; N.I.P.S.; conceptualization, and methodology assistance; N.A.M.; review, resources, and data curation. All authors have read and agreed to the published version of the manuscript.

Funding: This research was funded by Geran Inisiatif Putra Universiti Putra Malaysia, UPM/GP/2017/ 9568800.

Institutional Review Board Statement: Not applicable.

Informed Consent Statement: Not applicable.

Data Availability Statement: Not applicable.

Acknowledgments: The authors would like to acknowledge the financial contribution of the Ministry of Science, Technology, and Innovation (MOSTI), Malaysia, for funding this research under the Science Fund (Grant number: 05-01-04-SF0750).

Conflicts of Interest: The authors declare no conflict of interest.

\section{References}

1. Frisvad, J.C.; Hubka, V.; Ezekiel, C.N.; Hong, S.B.; Nováková, A.; Chen, A.J.; Arzanlou, M.; Larsen, T.O.; Sklenář, F.; Mahakarnchanakul, W.; et al. Taxonomy of Aspergillus section Flavi and their production of aflatoxins, ochratoxins, and other mycotoxins. Stud. Mycol. 2019, 93, 1-63. [CrossRef] [PubMed]

2. Pankaj, S.; Shi, H.; Keener, K.M. A review of novel physical and chemical decontamination technologies for aflatoxin in food. Trends Food Sci. Technol. 2017, 71,73-83. [CrossRef]

3. Lizárraga-Paulín, E.G.; Miranda-Castro, S.P.; Moreno-Martínez, E.; Torres-Pacheco, I.; Lara-Sagahón, A.V. Novel methods for preventing and controlling aflatoxins in food: A worldwide daily challenge. In Aflatoxins-Recent Advances and Future Prospects; Razzaghi-Abyaneh, M., Ed.; InTech: Rijeka, Croatia, 2013; pp. 93-128.

4. Burger, H.; Shephard, G.; Louw, W.; Rheeder, J.; Gelderblom, W. The mycotoxin distribution in maize milling fractions under experimental conditions. Int. J. Food Microbiol. 2013, 165, 57-64. [CrossRef]

5. Lombard, M.J. Mycotoxin exposure and infant and young child growth in Africa: What do we know? Ann. Nutr. Metab. 2014, 64 (Suppl. 2), 42-52. [CrossRef] [PubMed]

6. Wagacha, J.; Muthomi, J. Mycotoxin problem in Africa: Current-status, implications for food safety and health and possible management strategies. Int. J. Food Microbiol. 2008, 124, 1-12. [CrossRef] [PubMed]

7. Iimura, K.; Furukawa, T.; Yamamoto, T.; Negishi, L.; Suzuki, M.; Sakuda, S. The mode of action of cyclo (L-Ala-L-Pro) in inhibiting aflatoxin production of Aspergillus flavus. Toxins 2017, 9, 219. [CrossRef] [PubMed]

8. Shuaib, F.M.; Ehiri, J.; Abdullahi, A.; Williams, J.H.; Jolly, P.E. Reproductive health effects of aflatoxins: A review of the literature. Reprod. Toxicol. 2010, 29, 262-270. [CrossRef] [PubMed]

9. Bhat, R.; Rai, R.V.; Karim, A.A. Mycotoxins in food and feed: Present status and future concerns. Compr. Rev. Food Sci. Food Saf. 2010, 9, 57-81.

10. Chen, M.T.; Hsu, Y.H.; Wang, T.S.; Chien, S.W. Mycotoxin monitoring for commercial foodstuffs in Taiwan. J. Food Drug Anal. 2016, 24, 147-156. [CrossRef]

11. Williams, J.H.; Phillips, T.D.; Jolly, P.E.; Stiles, J.K.; Jolly, C.M.; Aggarwal, D. Human aflatoxicosis in developing countries: A review of toxicology, exposure, potential health consequences, and interventions. Am. J. Clin. Nutr. 2004, 80, 1106-1122. [CrossRef]

12. Fan, S.; Li, Q.; Sun, L.; Du, Y.; Xia, J.; Zhang, Y. Simultaneous determination of aflatoxin $B_{1}$ and $M_{1}$ in milk, fresh milk, and milk powder by LC-MS/MS utilizing online turbulent flow chromatography. Food Addit. Contam. A 2015, 32, 1175-1184. [CrossRef] [PubMed] 
13. Giovati, L.; Magliani, W.; Ciociola, T.; Santinoli, C.; Conti, S.; Polonelli, L. AFM 1 in milk: Physical, biological, and prophylactic methods to mitigate contamination. Toxins 2015, 7, 4330-4349. [CrossRef] [PubMed]

14. Monson, M.S.; Cardona, C.J.; Coulombe, R.A.; Reed, K.M. Hepatic transcriptome responses of domesticated and wild turkey embryos to aflatoxin $\mathrm{B}_{1}$. Toxins 2016, 8, 16. [CrossRef] [PubMed]

15. Rajkovic, A.; Uyttendaele, M.; Debevere, J. Computer-aided boar semen motility analysis for cereulide detection in different food matrices. Int. J. Food Microbiol. 2007, 114, 92-99. [CrossRef]

16. Verma, R.; Nair, A. Ameliorative effect of vitamin E on aflatoxin-induced lipid peroxidation in the testis of mice. Asian J. Androl. 2001, 3, 217-221.

17. Yuan, S.; Wu, B.; Yu, Z.; Fang, J.; Liang, N.; Zhou, M.; Peng, X. The mitochondrial and endoplasmic reticulum pathways involved in the apoptosis of bursa of Fabricius cells in broilers exposed to dietary aflatoxin $B_{1}$. Oncotarget 2016, 7, 65295. [CrossRef] [PubMed]

18. Peles, F.; Sipos, P.; Gyo"ri, Z.; Pfliegler, W.P.; Giacometti, F.; Serraino, A.; Pagliuca, G.; Gazzotti, T.; Pócsi, I. Adverse effects, transformation, and channeling of aflatoxins into food raw materials in livestock. Front. Microbiol. 2019, 10, 286. [CrossRef]

19. Jalili, M. A review on aflatoxins reduction in food. Iran. J. Health Saf. Environ. 2015, 3, 445-459.

20. Maleki, F.; Abdi, S.; Davodian, E.; Haghani, K.; Bakhtiyari, S. Exposure of infants to aflatoxin M1 from mother's breast milk in Ilam, Western Iran. Osong Public Health Res. Perspect. 2015, 6, 283-287. [CrossRef]

21. Warth, B.; Braun, D.; Ezekiel, C.N.; Turner, P.C.; Degen, G.H.; Marko, D. Biomonitoring of mycotoxins in human breast milk: Current state and future perspectives. Chem. Res. Toxicol. 2016, 29, 1087-1097. [CrossRef]

22. Ali, N.; Hashim, N.H.; Shuib, N.S. Natural occurrence of aflatoxins and ochratoxin A in processed spices marketed in Malaysia. Food Addit. Contam. Part A 2015, 32, 518-532. [CrossRef] [PubMed]

23. McGuire, S. World cancer report, 2014. Geneva, Switzerland: World Health Organization, the international agency for cancer research, WHO Press, 2015. Adv. Nutr. 2016, 7, 418-419. [CrossRef]

24. Fouad, M.A.; Ruan, D.; El-Senousey, K.H.; Chen, W.; Jiang, S.; Zheng, C. Harmful effects and control strategies of aflatoxin B1 produced by Aspergillus flavus and Aspergillus parasiticus strains on poultry: Review. Toxins (Basel) 2019, 11, 176. [CrossRef]

25. Benkerroum, N. Mycotoxins in dairy products: A review. Int. Dairy J. 2016, 62, 63-75. [CrossRef]

26. McGlynn, K.A.; London, W.T. Epidemiology and natural history of hepatocellular carcinoma. Best Pract. Res. Clin. Gastroenterol. 2005, 19, 3-23. [CrossRef]

27. Male, D. Challenges Facing Foodborne Mycotoxin Regulation and Public Health Consequences of Exposure in Children under 5 Years of Age. Ph.D. Thesis, Michigan State University, East Lansing, MI, USA, 2017; pp. 1-166.

28. El-Serag, H.B. Epidemiology of hepatocellular carcinoma. Liver Biol. Pathol. 2020, 758-772. [CrossRef]

29. Bruix, J.; Merle, P.; Granito, A.; Huang, Y.H.; Bodoky, G.; Yokosuka, O.; Masi, G. LBA-03 Efficacy and safety of regorafenib versus placebo in patients with hepatocellular carcinoma (HCC) progressing on sorafenib: Results of the international, randomized phase 3 RESORCE trial. Ann. Oncol. 2016, 27, 140-141. [CrossRef]

30. Yoshida, H.; Mamada, Y.; Taniai, N.; Uchida, E. Spontaneous ruptured hepatocellular carcinoma. Hepatol. Res. 2016, 46, 13-21. [CrossRef]

31. Liu, Y.; Wu, F. Globalburden of aflatoxin-induced hepatocellular carcinoma: A risk assessment. Environ. Health Perspect. 2010, 118, 818-824. [CrossRef]

32. Agag, B. Mycotoxins in foods and feeds: 1-aflatoxins. Ass. Univ. Bull. Environ. Res. 2004, 7, 173-205.

33. Storvik, M.; Huuskonen, P.; Kyllönen, T.; Lehtonen, S.; El-Nezami, H.; Auriola, S.; Pasanen, M. Aflatoxin B 1 -a potential endocrine disruptor-up-regulates CYP19A1 in JEG-3 cells. Toxicol. Lett. 2011, 202, 161-167. [CrossRef] [PubMed]

34. Ataman, M.B.; Bucak, M.N.; Çoyan, K. Esterified glucomannan improves the aflatoxin-induced damage of sperm parameters during liquid storage of ram semen at $5{ }^{\circ} \mathrm{C}$. Cryobiology 2014, 68, 405-410. [CrossRef] [PubMed]

35. Gong, Y.Y.; Watson, S.; Routledge, M.N. Aflatoxin exposure and associated human health effects, a review of epidemiological studies. Food Saf. 2016, 4, 14-27. [CrossRef] [PubMed]

36. Ingawale, D.K.; Mandlik, S.K.; Naik, S.R. Models of hepatotoxicity and the underlying cellular, the biochemical and immunological mechanism (s): A critical discussion. Environ. Toxicol. Pharmacol. 2014, 37, 118-133. [CrossRef]

37. Alsayyah, A.; ElMazoudy, R.; Al-Namshan, M.; Al-Jafary, M.; Alaqeel, N. Chronic neurodegeneration by aflatoxin B 1 depends on alterations of brain enzyme activity and immunoexpression of astrocyte in male rats. Ecotoxicol. Environ. Saf. 2019, $182,109407$. [CrossRef] [PubMed]

38. Ayalew, A.; Kimanya, M.; Matumba, L.; Bandyopadhyay, R.; Menkir, A.; Cotty, P. Controlling aflatoxins in maize in Africa: Strategies, challenges, and opportunities for improvement. Achiev. Sustain. Cultiv. Maize 2017, 2, 1-24.

39. Lewis, L.; Onsongo, M.; Njapau, H.; Schurz-Rogers, H.; Luber, G.; Kieszak, S.; Misore, A. Aflatoxin contamination of commercial maize products during an outbreak of acute aflatoxicosis in eastern and central Kenya. Environ. Health Perspect. 2005, $113,1763$. [CrossRef]

40. Probst, C.; Njapau, H.; Cotty, P.J. The outbreak of an acute aflatoxicosis in Kenya in 2004: Identification of the causal agent. Appl. Environ. Microbiol. 2007, 73, 2762-2764. [CrossRef]

41. Shephard, G. Mycotoxins in the context of food risks and nutrition issues. In The Mycotoxin Factbook: Food and Feed Topics; Barug, D., Bhatnagar, D., Van Egmond, H.P., Van Der Kamp, J.W., Van Osenbruggen, W.A., Visconti, A., Eds.; Wageningen Academic Publishers: Wageningen, The Netherlands, 2006; pp. 21-36. 
42. Zain, M.E. Impact of mycotoxins on humans and animals. J. Saudi Chem. Soc. 2011, 15, 129-144. [CrossRef]

43. Afsah-Hejri, L.; Jinap, S.; Hajeb, P.; Radu, S.; Shakibazadeh, S. A review on mycotoxins in food and feed: Malaysia case study. Compr. Rev. Food Sci. Food Saf. 2013, 12, 629-651. [CrossRef]

44. Gibb, H.; Devleesschauwer, B.; Bolger, P.M.; Wu, F.; Ezendam, J.; Cliff, J.; Zeilmaker, M.; Verger, P.; Pitt, J.; Baines, J.; et al. World Health Organization estimates of the global and regional disease burden of four foodborne chemical toxins, 2010: A data synthesis. F1000 Res. 2015, 4, 1393. [CrossRef] [PubMed]

45. Coppock, R.W.; Christian, R.G.; Jacobsen, B.J. Aflatoxins. In Veterinary Toxicology, 3rd ed.; Gupta, R.C., Ed.; Academic Press: Cambridge, MA, USA, 2018; pp. 983-994.

46. Kaplan, N.M.; Palmer, B.F.; Revankar, S.G. Clinical implications of mycotoxins and Stachybotrys. Am. J. Med. Sci. 2003, 325, 262-274. [CrossRef]

47. Van Egmond, H.P.; Schothorst, R.C.; Jonker, M.A. Regulations relating to mycotoxins in food. Anal. Bioanal. Chem. 2007, 389, 147-157. [CrossRef]

48. Klich, M.A.; Pitt, J.I. A laboratory guide to common Aspergillus species and their Teleomorphs. Div. Food Res. 1988, 7, $245-256$.

49. Horn, B.W.; Dorner, J.W. Regional differences in the production of aflatoxin $\mathrm{B}_{1}$ and cyclopiazonic acid by soil isolates of Aspergillus flavus alonga transect the United States. Appl. Environ. Microbiol. 1999, 65, 1444-1449. [CrossRef] [PubMed]

50. Horn, B.W.; Greene, R.L.; Sobolev, V.S.; Dorner, J.W.; Powell, J.H.; Layton, R.C. Association of morphology and mycotoxin production with vegetative compatibility groups in Aspergillus flavus, A. parasiticus, and A. tamarii. Mycologia 1996, 88, 574-587. [CrossRef]

51. Tran-Dinh, N.; Kennedy, I.; Bui, T.; Carter, D. Survey of Vietnamese peanuts, corn, and soil for the presence of Aspergillus flavus and Aspergillus parasiticus. Mycopathologia 2009, 168, 257-268. [CrossRef]

52. Zanon, M.S.A.; Barros, G.G.; Chulze, S.N. Non-aflatoxigenic Aspergillus flavus as potential biocontrol agents to reduce aflatoxin 594 contamination in peanuts harvested in Northern Argentina. Int. J. Food Microbiol. 2016, 231, 63-68. [CrossRef] [PubMed]

53. Payne, G.A.; Brown, M.P. Genetics and physiology of aflatoxin biosynthesis. Annu. Rev. Phytopathol. 1998, 36, 329-362. [CrossRef]

54. Sashidhar, R.B.; Ramakrishna, Y.; Bhat, V.R. Molds and mycotoxins in sorghum stored in traditional containers in India. J. Stored Prod. Res. 1992, 28, 257-260. [CrossRef]

55. Bock, C.H.; Mackey, B.; Cotty, P.J. Population dynamics of Aspergillus flavus in the air of an intensively cultivated region of southwest Arizona. Plant. Pathol. 2004, 53, 422-433. [CrossRef]

56. Wu, F.; Khlangwiset, P. Health economic impacts and cost-effectiveness of aflatoxin reduction strategies in Africa: Case studies in biocontrol and post-harvest interventions. Food Addit. Contam. A 2010, 27, 496. [CrossRef] [PubMed]

57. Dorner, J. Management and prevention of mycotoxins in peanuts. Food Addit. Contam. 2008, 25, 203-208. [CrossRef]

58. Brown, R.L.; Menkir, A.; Chen, Z.Y.; Bhatnagar, D.; Yu, J.; Yao, H.; Cleveland, T.E. Breeding aflatoxin-resistant maize lines using recent advances in technologies-a review. Food Addit. Contam. Part A 2013, 30, 1382-1391. [CrossRef] [PubMed]

59. Shetty, P.H.; Jespersen, L. Saccharomyces cerevisiae and lactic acid bacteria as potential mycotoxin decontaminating agents. Trends Food Sci. Technol. 2006, 17, 48-55. [CrossRef]

60. Jane, C.; Kiprop, E.; Mwamburi, L. Biocontrol of aflatoxins in corn using atoxigenic Aspergillus flavus. Int. J. Sci. Res. 2012, 3, 2319-7064.

61. Sanders, T.H.; Blankenship, P.D.; Cole, R.J.; Hill, R.A. Effect of soil temperature and drought on peanut pod and stem temperatures relative to Aspergillus flavus invasion and aflatoxin contamination. Mycopathologia 1984, 86, 51-54. [CrossRef]

62. Schmitt, S.G.; Harburgh, C.R. Distribution, and measurement of aflatoxin in 1983 Iowa corn. Cereal Chem. 1989, 66, 165-168.

63. Abbas, H.K.; Weaver, M.A.; Horn, B.W.; Carbone, I.; Monacell, J.T.; Shier, W.T. Selection of Aspergillus flavus isolates for biological control of aflatoxins in corn. Toxin Rev. 2011, 30, 59-70. [CrossRef]

64. Ehrlich, K.C.; Cotty, P.J. An isolate of Aspergillus flavus used to reduce aflatoxin contamination in cottonseed has a defective polyketide synthase gene. Appl. Microbiol. Biotechnol. 2004, 65, 473-478. [CrossRef]

65. Wyatt, R.D. Mycotoxins and Animal Foods; Smith, J.E., Henderson, R.S., Eds.; CRC Press: Boca Ratan, Poultry, $1991 ;$ pp. $553-605$.

66. Prakash, R.; Jha, S. Basics of the genus Aspergillus. Int. J. Res. Bot. 2014, 4, 26-30.

67. Hua, S.S.T.; McAlpin, C.E.; Chang, P.K.; Sarreal, S.B.L. Characterization of aflatoxigenic and non-aflatoxigenic Aspergillus flavus isolates from pistachio. Mycotoxin Res. 2012, 28, 67-75. [CrossRef] [PubMed]

68. Vaamonde, G.; Patriarca, A.; Pinto, V.F.; Comerio, R.; Degrossi, C. Variability of aflatoxin and cyclopiazonic acid production by Aspergillus section Flavi from different substrates in Argentina. Int. J. Food Microbiol. 2003, 88, 79-84. [CrossRef]

69. Bandyopadhyay, R.; Ortega-Beltran, A.; Akande, A.; Mutegi, C.; Atehnkeng, J.; Kaptoge, L.; Cotty, P. Biological control of aflatoxins in Africa: Current status and potential challenges in the face of climate change. World Mycotoxin J. 2016, 9, 771-789. [CrossRef]

70. Chang, P.K.; Abbas, H.K.; Weaver, M.A.; Ehrlich, K.C.; Scharfenstein, L.L.; Cotty, P.J. Identification of genetic defects in the atoxigenic biocontrol strain Aspergillus flavus $\mathrm{K} 49$ reveals the presence of a competitive recombinant group in field populations. Int. J. Food Microbiol. 2012, 154, 192-196. [CrossRef] [PubMed]

71. Huang, C.; Jha, A.; Sweany, R.; DeRobertis, C.; Damann, K.E. Intraspecific aflatoxin inhibition in Aspergillus flavus is thigmoregulated, independent of the vegetative compatibility group, and is strain-dependent. PLoS ONE 2011, 6, e23470. [CrossRef]

72. Cotty, P.J. Effect of harvest date on aflatoxin contamination of cottonseed. Plant. Dis. 1991, 75, 312-314. [CrossRef] 
73. Dorner, J.W.; Cole, R.J.; Sanders, T.H.; Blankenship, P.D. Interrelationship of kernel water activity, soil temperature, maturity and phytoalexin production in preharvest aflatoxin contamination of drought-stressed peanuts. Mycopathologia 1989, 105, 117-128. [CrossRef]

74. Wilson, D.M.; Mubatanhema, W.; Jurjevic, Z. Biology, and ecology of mycotoxigenic Aspergillus species related to economic and health concerns. Adv. Exp. Med. Biol. 2002, 504, 3-17.

75. Jasutiene, I.; Garmiene, G.; Kulikauskiene, M. Pasteurisation and fermentation effects on Aflatoxin M1 stability. Milchwissenschaft 2006, 61, 75-79.

76. Raters, M.; Matissek, R. Thermal stability of aflatoxin $B_{1}$ and ochratoxin A. Mycotoxin Res. 2008, 24, 130-134. [CrossRef] [PubMed]

77. Assaf, J.C.; Nahle, S.; Chokr, A.; Louka, N.; Atoui, A.; El Khoury, A. Assorted methods for the decontamination of aflatoxin M1 in milk using microbial adsorbents. Toxins 2019, 11, 304. [CrossRef] [PubMed]

78. Smith, J.E.; Moss, M.O. Mycotoxins: Formation, Analysis, and Significance; John Wiley and Sons: New York, NY, USA, 1985 ; p. 148.

79. Ahlberg, S.H.; Joutsjoki, V.; Korhonen, H.J. Potential of lactic acid bacteria in aflatoxin risk mitigation. Int. J. Food Microbiol. 2015, 207, 87-102. [CrossRef]

80. Tian, F.; Chun, H.S. Natural products for preventing and controlling aflatoxin contamination of food. In Aflatoxin-Control, Analysis, Detection and Health Risks; Abdulra'uf, L., Ed.; IntechOpen: London, UK, 2017; pp. 13-44.

81. Degola, F.; Berni, E.; Restivo, F.M. Laboratory tests for assessing the efficacy of atoxigenic Aspergillus flavus strains as biocontrol agents. Int. J. Food Microbiol. 2011, 146, 235-243. [CrossRef] [PubMed]

82. Wu, F. Global effects of aflatoxin in maize: Trade and human health. World Mycotoxin J. 2015, 8, 137-142. [CrossRef]

83. Wu, F.; Bhatnagar, D.; Bui-Klimke, T.; Carbone, I.; Hellmich, R.; Munkvold, G.; Paul, P.; Payne, G.; Takle, E. Climate change affects mycotoxin risks in US maize. World Mycotoxin J. 2011, 4, 79-93. [CrossRef]

84. Dorner, J.W.; Cole, R.J. Effect of application of nontoxigenic strains of Aspergillus flavus and A. parasiticus on subsequent aflatoxin contamination peanuts in storage. J. Stored Prod. Res. 2002, 38, 329-339. [CrossRef]

85. Dorner, J.W.; Cole, R.J.; Connick, W.J.; Daigle, D.L.; McGuire, M.R.; Shasha, B.S. Evaluation of biological control formulations to reduce aflatoxin contamination in peanuts. Biol. Control. 2003, 26, 318-324. [CrossRef]

86. Mishra, H.N.; Das, C. A review on biological control and metabolism of aflatoxin. Crit. Rev. Food Sci. Nutr. 2003, 43, 245-264. [CrossRef]

87. Dorner, J.W. Biological control of aflatoxin contamination of crops. J. Toxicol. Toxin Rev. 2004, 23, 425-450. [CrossRef]

88. Kimura, N.; Hirano, S. Inhibitory strains of Bacillus subtilis for growth and aflatoxin production of aflatoxigenic fungi. J. Agric. Biol. Chem. 1988, 52, 1173-1179. [CrossRef]

89. Bolton, H.J.; Elliott, L.F.; Turko, R.F.; Kennedy, A.C. Rhizoplane colonization of pea seedling of Rhizobium leguminosara and deleterious root colonizing Pseudomonas spp. and effects on plant growth. Plant. Soil. 1990, 123, 121-124. [CrossRef]

90. Thomashow, L.S.; Weller, D.M.; Bonsall, R.F.; Pierson, I.S. Production of the antibiotic phenazine-I carboxylic acid by fluorescent Pseudomonas spp. in the rhizosphere of wheat. Appl. Environ. Microbiol. 1990, 56, 908-912. [CrossRef] [PubMed]

91. Loper, J.E.; Buyer, J.S. Siderophores in microbial interaction on plant surfaces. Mol. Plant. Interact. 1991, 4, 5-13. [CrossRef]

92. Varma, J.; Dubey, N.K. Prospective of botanical and microbial products as pesticides of tomorrow. Curr. Sci. 1999, 76, 172-179.

93. Bonsall, R.F.; Weller, D.M.; Thomashow, L.S. Quantification of 2, 4-diacetyl phloroglucinol produced by fluorescent Pseudomonas spp. in vitro and the rhizosphere of wheat. Appl. Environ. Microbiol. 1997, 63, 951-955. [CrossRef] [PubMed]

94. Faraj, M.K.; Smith, J.E.; Harran, G. Aflatoxin biodegradation: Effects of temperature and microbes. Mycol. Res. 1993, 97, 1388-1392. [CrossRef]

95. Misaghi, I.J.; Cotty, P.J.; Decianne, D.M. Bacterial antagonist of Aspergillus flavus. Biocontrol Sci. Technol. 1995, 5, $387-392$. [CrossRef]

96. Kong, Q.; Shan, S.; Liu, Q.; Wang, X.; Yu, F. Biocontrol of Aspergillus flavus on peanut kernels by use of a strain of marine Bacillus megaterium. Int. J. Food Microbiol. 2010, 139, 31-35. [CrossRef]

97. Brown, R.I.; Cotty, P.J.; Cleveland, T.E. Reduction in aflatoxin content of maize by atoxigenic strains of Aspergillus flavus. J. Food Prot. 1991, 54, 623-626. [CrossRef]

98. Cotty, P.J. Influence of field application of an atoxigenic strain of Aspergillus flavus on the populations of A. flavus infecting cotton bolls and the aflatoxin content cottonseed. Phytopathology 1994, 84, 1270-1277. [CrossRef]

99. Dorner, J.W. Biological control of aflatoxin contamination in corn using a nontoxigenic strain of Aspergillus flavus. J. Food Prot. 2009, 72, 801-804. [CrossRef]

100. Das, M.K.; Ehrlich, K.C.; Cotty, P.J. Use of pyrosequencing to quantify the incidence of a specific Aspergillus flavus strain within complex fungal communities associated with commercial cotton crops. Phytopathology 2008, 98, 282-288. [CrossRef]

101. Chulze, S. Strategies to reduce mycotoxin levels in maize during storage: A review. Food Addit. Contam. 2010, $27,651-657$. [CrossRef]

102. Rani, P.R.; Chelladurai, V.; Jayas, D.S.; White, N.D.G.; Kavitha-Abirami, C.V. Storage studies on pinto beans under different moisture contents and temperature regimes. J. Stored Prod. Res. 2013, 52, 78-85. [CrossRef]

103. Probst, C.; Bandyopadhyay, R.; Cotty, P.J. Diversity of aflatoxin-producing fungi and their impact on food safety in sub-Saharan Africa. Int. J. Food Microbiol. 2014, 174, 113-122. [CrossRef]

104. Bandyopadhyay, R.; Kumar, M.; Leslie, J.F. Relative severity of aflatoxin contamination of cereal crops in West Africa. Food Addit. Contam. 2007, 24, 1109-1114. [CrossRef] 
105. Donner, M.; Atehnkeng, J.; Sikora, R.A.; Bandyopadhyay, R.; Cotty, P.J. Molecular characterization of atoxigenic strains for biological control of aflatoxins in Nigeria. Food Addit. Contam. 2010, 27, 576-590. [CrossRef]

106. Das, D.; Selvaraj, R.; Bhat, M.R. Optimization of inulinase production by a newly isolated strain Aspergillus flavus var. flavus by solid-state fermentation of Saccharum arundinaceum. Biocatal. Agric. Biotechnol. 2019, 22, 101363.

107. Abbas, H.K.; Zablotowicz, R.M.; Weaver, M.A.; Shier, W.T.; Bruns, H.A.; Bellaloui, N.; Abel, C.A. Implications of Bt traits on mycotoxin contamination in maize: Overview and recent experimental results in the Southern United States. J. Agric. Food Chem. 2013, 61, 11759-11770. [CrossRef]

108. Ehrlich, K. Effect on aflatoxin production of competition between wild type and mutant strains of Aspergillus parasiticus. Mycopathologia 1987, 97, 93-96. [CrossRef]

109. Cotty, P.J. Aflatoxin-producing potential of communities of Aspergillus section flavi from cotton-producing areas in the United States. Mycol. Res. 1997, 101, 698-704. [CrossRef]

110. Hatlen, T.J.; Filler, S.G.; Bayer, A.; Shah, S.; Shodhan, S.; Van, T.T. Aspergillus endocarditis diagnosed by fungemia plus serum antigen testing. Med. Mycol. Case Rep. 2019, 23, 1-3. [PubMed]

111. Brown, R.L.; Chen, Z.Y.; Cleveland, T.E.; Russin, J.S. Advances in the development of host resistance in corn to aflatoxin contamination Aspergillus flavus. Phytopathology 1999, 89, 113-117. [CrossRef]

112. Cotty, P.J.; Bhatnagar, D. Variability among atoxigenic Aspergillus flavus strains in the ability to prevent aflatoxin contamination and production of aflatoxin biosynthetic pathway enzymes. Appl. Environ. Microbiol. 1994, 60, 2248-2251. [CrossRef]

113. Cotty, P.J.; Mellon, J.E. Ecology of aflatoxin producing fungi and biocontrol of aflatoxin contamination. Mycotoxin Res. 2006, 22, 110-117. [CrossRef]

114. Khan, R.; Ghazali, F.M.; Mahyudin, N.A.; Samsudin, N.I.P. Co-Inoculation of aflatoxigenic and non-aflatoxigenic strains of Aspergillus flavus to assess the efficacy of non-aflatoxigenic strains in growth inhibition and aflatoxin $\mathrm{B}_{1}$ reduction. Agriculture 2021, 11, 1-11.

115. Chang, P.K.; Hua, S.S.T. Nonaflatoxigenic Aspergillus flavus TX9-8 competitively prevents aflatoxin accumulation by A. flavus isolates of large and small sclerotial morphotypes. Int. J. Food Microbiol. 2007, 114, 275-279. [CrossRef]

116. Atehnkeng, J.; Ojiambo, P.; Ikotun, T.; Sikora, R.; Cotty, P.; Bandyopadhyay, R. Evaluation of atoxigenic isolates of Aspergillus flavus as potential biocontrol agents for aflatoxin in maize. Food Addit. Contam. 2008, 25, 1264-1271. [CrossRef] [PubMed]

117. Ehrlich, K.; Ciegler, A.; Klich, M.A.; Lee, L. Fungal competition and mycotoxin production on corn. Experientia 1985, 41, 691-693. [CrossRef]

118. Lyn, M.; Abbas, H.; Zablotowicz, R.; Johnson, B. Delivery systems for biological control agents to manage aflatoxin contamination of pre-harvest maize. Food Addit. Contam. Part A 2009, 26, 381-387. [CrossRef] [PubMed]

119. Pitt, J.; Hocking, A.D. Mycotoxins in Australia: Biocontrol of aflatoxin in peanuts. Mycopathologia 2006, 162, 233-243. [CrossRef] [PubMed]

120. Köhl, J.; Molhoek, W. Effect of water potential on conidial germination and antagonism of Ulocladium atrum against Botrytis cinerea. Phytopathology 2001, 91, 485-491. [CrossRef] [PubMed]

121. Mendoza, J.; Sabillón, L.; Martinez, W.; Campabadal, C.; Hallen-Adams, H.; Bianchini, A. Traditional maize post-harvest management practices amongst smallholder farmers in Guatemala. J. Stored Prod. Res. 2017, 71, 14-21. [CrossRef]

122. Cotty, P.J.; Jaime-Garcia, R. Influences of climate on aflatoxin producing fungi and aflatoxin contamination. Int. J. Food Microbiol. 2007, 119, 109-115. [CrossRef]

123. Accinelli, C.; Mencarelli, M.; Saccà, M.L.; Vicari, A.; Abbas, H.K. Managing and monitoring Aspergillus flavus in corn using bioplastic-based formulations. Crop. Prot. 2012, 32, 30-35. [CrossRef]

124. Lewis, M.H.; Carbone, I.; Luis, J.M.; Payne, G.A.; Bowen, K.L.; Hagan, A.K.; Kemerait, R.; Heiniger, R.; Ojiambo, P.S. Biocontrol strains differentially shift the genetic structure of indigenous soil populations of Aspergillus flavus. Front. Microbiol. 2019, 10, 1738. [CrossRef]

125. Mamo, F.T.; Selvaraj, J.N.; Wang, Y.; Liu, Y. Recent Developments in the Screening of Atoxigenic Aspergillus flavus towards Aflatoxin Biocontrol. J. Appl. Environ. Microbiol. 2017, 5, 20-30.

126. Kabak, B.; Dobson, A.D. Biological strategies to counteract the effects of mycotoxins. J. Food Prot. 2009, 72, 2006-2016. [CrossRef]

127. Köhl, J.; Langerak, C.J.; Meekes, E.T.M.; Molhoek, W.M.L. Biological control of Alternaria radicina in seed production of carrots with Ulocladium atrum. Seed Sci. Tech. 2004, 32, 857-861. [CrossRef]

128. Galumbic, C.; Kulik, M.M. Fungal Spoilage in Stored Crops and its Control. In Aflatoxin: Scientific Background, Control, and Implications; Academic Press: Cambridge, MA, USA, 2012; Chapter XI; pp. 307-332.

129. Lahouar, A.; Marin, S.; Crespo-Sempere, A.; Saïd, S.; Sanchis, V. Influence of temperature, water activity, and incubation time on fungal growth and production of ochratoxin A and zearalenone by toxigenic Aspergillus tubingensis and Fusarium incarnatum isolates in sorghum seeds. Int. J. Food Microbiol. 2017, 242, 53-60. [CrossRef] [PubMed]

130. Reed, C.; Doyungan, S.; Ioerger, B.; Getchell, A. The response of storage molds to different initial moisture contents of maize (corn) stored at 25C, and effect on respiration rate and nutrient composition. J. Stored Prod. Res. 2007, 43, 443-458. [CrossRef]

131. Garcia-Gonzalez, L.; Geeraerd, A.H.; Spilimbergo, S.; Elst, K.; Van Ginneken, L.; Debevere, J.; Devlieghere, F. High-pressure carbon dioxide inactivation of microorganisms in foods: The past, the present, and the future. Int. J. Food Microbiol. 2007, 117, 1-28. [CrossRef] [PubMed] 
132. Reddy, B.; Brijitha, N.; Raghavender, C. Aflatoxin contamination in insect-damaged seeds of horsegram under storage. Mycotoxin Res. 2005, 21, 187-191. [CrossRef] [PubMed]

133. Girdthai, T.; Jogloy, S.; Vorasoot, N.; Akkasaeng, C.; Wongkaew, S.; Holbrook, C.C.; Patanothai, A. Associations between physiological traits for drought tolerance and aflatoxin contamination in peanut genotypes under terminal drought. Plant Breed. 2010, 129, 693-699. [CrossRef]

134. Hill, R.A.; Blankenship, P.D.; Cole, R.J.; Sanders, T.H. Effects of soil moisture and temperature on the preharvest invasion of peanuts by the Aspergillus flavus group and subsequent aflatoxin development. Appl. Environ. Microbiol. 1983, 45, 628-633. [CrossRef]

135. Reddy, K.R.N.; Reddy, C.S.; Muralidharan, K. Potential of botanicals and biocontrol agents on growth and aflatoxin production Aspergillus flavus infecting rice grains. Food Control. 2009, 20, 173-178. [CrossRef]

136. Magan, N. Ecophysiology of biocontrol agents for improved competence in the phyllosphere. Microb. Ecol. Aerial Plant. Surf. 2006, 1, 149-164.

137. Gasch, A.P. Comparative genomics of the environmental stress response in ascomycete fungi. Yeast 2007, 24, 961-976. [CrossRef]

138. Nesci, A.; Etcheverry, M.; Magan, N. Osmotic and matric potential effects on growth, sugar alcohol, and sugar accumulation by Aspergillus section Flavi strains from Argentina. J. Appl. Microbiol. 2004, 96, 965-972. [CrossRef]

139. Abadias, M.; Teixidó, N.; Usall, J.; Viñas, I.; Magan, N. Improving water stress tolerance of the biocontrol yeast Candida sake grown in molasses-based media by physiological manipulation. Can. J. Microbiol. 2001, 47, 123-129. [CrossRef] [PubMed] 